\title{
LINGUAL INTERVENTIONS IN DARIO FO
}

Whereas we associate articulate self-expression with the theatte, comic theatre has pricted itself on a wide range of invented speech-types which subvert usual patterns of expression, playing with the audience's idea of normal performance. One form of such a subversion of expectations has been the use of invented language on stage. Some call this gibberish, some "macaronic speech," the playwright and actor Dario Fo names this babble grammelot. Fo explains that in grammelot the actor is freed from the confines of national borders since the performance is physicalized and the language constructed in such a way as to be meaningful by its power of suggestion rather than by semantic sense. Inspired by the medieval performance tradition started by the giullari (in Italian) or jongleurs (in French), itinerant traveling performers whose acrobatics and verbal antics delighted their audiences, Fo utilizes an almost "anti-theatrical" technique of nonsense language which seems to challenge the audience more than to feed into its accepted notions of communication. ${ }^{1}$ In his theatre pieces, particularly his enactments of comic monologues of Zanni (servant characters drawn from the commedia dell arte). Fo embraces a popular performance of the body where imaginary, child-like babble seems to emerge in consort with physical gestures, supplanting coherent speech as a form of legitimate communication.

The eloquent nonsense which Fo invents is more than an easy access point for performers wanting to reach different cultural and linguistic groups by using a non-national language. Grammelot is a form of co-creation melding audience and performer in order to invent a possible communication that is equally meaningful to utterer and listener. In that sense, in Fo's performances, language acts as a central trope suggesting the potential of theatre to be an active clomain for re-shaping reality. In this article I will locate the theatre practice in history as well as in contemporary performances. focusing on the different realizations of the technique. I will also attempt a phenomenological analysis of the way language in these exchanges minimizes the distance between audience and performer. 


\section{An Historical Perspective on Nonsense on the Stage: When the "forbidden" is legitimated}

To suggest that Fo is the first performer to utilize nonsense language would be inaccurate considering the commedia dell'arte tradition which Fo himself draws from. The performance techniques that the sixteenth- and seventeenthcentury commedia dell arte performers used included stylized speech along with masks, costumes, music, and a complex physical and gestural expression. Nonsense became a staple element associated with the Zanni, or servant character identified with Northern Italy, particularly with the town of Bergamo. The Zanni, as Harlequin, spoke Bergamask, the regional dialect, which was largely indecipherable to audiences from other regions or from other countries. In order to compensate for this difficulty in comprehension, the actor clepicting the Zanni molded his movements in an expressive manner and incorporated a language that relied on phonetic suggestiveness more than on semantic congruency between the character's communication and the language spoken by the audience. This invented language facilitated the audience's comprehension much as Latin gibberish in medieval plays (such as Pierre Pathelin) relied on limited lexical recognition and on broader associations that particular sounds would have for the audience.

In addition, the Zanni held a special function within commedia dell'arte. Being the servant, he often reflected his audience more immediately than the characters of commedia erudita, the learned and scripted drama generally performed at academies and by "amateur" performers. The Zanni and his coperformers drew audiences from the court and also from the wider population as companies worked in stanze (rooms) as well as in plein aire: outdoors in piazzas and fairs. When the Zanni appeared, he was associated with the lewd performance of the early itinerant performers of the sixteenth century who showcased their bodies by performing daring stunts as well as reflecting scatological preoccupations with the body through enactments of bodily functions such as excretion and birth, as evidenced in one of the most important extant iconographic sources, the Recueil Fossard. ${ }^{2}$ And when the Zanni spoke nonsense he was expressing the mixed state of acceptance and exclusion experienced by the social station he represented. Among the Zanni's most famous enactments is that of hunger. Like the central figure in Kafka's "The Hunger Artist," the actor playing the Zanni literally had to perform his own hunger for the entertainment of his audiences, his only guarantee of being fed. Protest, which was not allowed within the rigid social hierarchy of the Renaissance, was thus surreptitiously voiced as the selfaware performer launched into a tirade about his desire to eat. 
Fo has preserved one of these hunger tirades in his own enactment of "The Starving Zanni", in which he first states his hunger and then proceeds to enact a self-cannibalizing mimic sequence. All throughout, his physical demonstrations of eating his own foot or knee are unclerscored by onomatopoeic sounds which clescribe his actions and suggest the goriness of his behavior. ${ }^{3}$ In this case, Fo's uttering nonsensical "babble[s] of sounds" in fact allows the Zanni to speak about a forbicklen topic: his hunger (Fo, Tricks 434.t). Since the normative language allows no room for complaint, the grammelot allows a language in which it is possib!e to voice opinions. By allow' ing the Zanni to speak in a language that is not real but which they understood, the audience tacitly takes part in the act of protesting their condition, and the performance event becomes transgressive.

In another example. Fo demonstrates the use of grammelot for protest today. This time, in "The American Technocrat," he turns his focus to English.

Today, English, particularly the version spoken in the Inited States, has become the language of the Empire. There is no avoiding the reality; it is the dominant language in absolute terms, and this fact has led to atn outbreak of lexical plagiarisms in Italy. You can observe it in scores of journalists who, gurgling with delight at their own intellect, never fail to introduce into each and every article they write at least fifty-five terms from American slang - look, scoop, mood, network, match, meeting, feeling. workshop - the list is endless. The imbecility indicates that we inhabit the frontiers of Empire" ( 74$)$.

At the time he was writing $/ l$ mamale minimo, in the middle to late eighties, the harsh criticism Fo directed to English was fueled by the escalating antagonisms of the United States and the former Soviet Union, whose mounting arsenals threatened, and still do, in various forms, our planet's safety. So, it is not difficult to see how American English would become a vehicle for criticizing the political machine which, in the late twentieth century, is the bastion of unchecked power. And who symbolizes the combination of mindless progress that leads to potentially destructive results better than the scientists who emerge from this power?

Thinking about this environment and these characters, I had the bright idea of attempting a monologue in sophisticated American grammelot, featuring a high-level scientific conference where an illustrious nuclear electronic physicist is holding forth" (7-4-75).

"This great technocrat," Fo informs us, 
would be explaining the science of robots with the relevant, comparative description of circuits, of relays, of computers, before proceeding to an account of the history of human flight, detailing early propeller planes with the internal combustion engine, and then going on to reactors and longrange missiles. .. (75).

The tedious description Fo offers of the technocrat's narrative already informs the general rhythm, pace, and listing quality that will be implicit in the grammelot and will reveal the gist of the monologue to non-grammelot speaking audience members. In addition, this grammelot includes various American stereotypical expressions, such as "Oh yes!" The evocation is also made up of sounds with wide vowels or emphasized r's, in addition to onomatopoeic utterances suggestive of the machine language of engines and propellers (80). For example, note the following description Fo offers of the scientist explaining starting a propeller plane engine:

Gets the engine started by turning the propeller, all accompanied by appropriate noises ... rrrraaaaa. Mimes cranking up a starting handle. The engine splutters into life: proooo too teeeeee . . repeats the sound produced by the propeller - rrrrrraaaaa. . . then the engine sounds prooooo tooo teeeeee. Scolds the engine as though it were an impudent child, refusing to do what it is told. He tells it (still in grammelot, obviously) 'No, the propeller goes irmrraaaaa, you're supposed to go proooo tooooo prooooo not prooo toooo teeee. Let's all try hard to get it right, shall we?' (74)

The action of anthropomorphising the engine signals the irrationality of the initially controlled scientist. The behavior hints at similarly uncontrolled actions by researchers who lack foresight into the potential applications their projects may have when in the hands of powver mongers and political entities. More broadly, just as the hungry Zanni's grammelot allows him to protest his measly conditions, the technocrat's grammelot allows a mockery of an otherwise all-powerful political entity, which, though aclvocating free speech, often cloes not look kindly on external, overt criticisms. The clowning aspect of the lecturer allow's the underpinning criticism of irrational, progress-oriented research into military technology to be heard.

Fo's use of grammelot in this performance of "The American Technocrat" allows him to utilize English without actually speaking the language properly. As opposed to "The Starving Zanni" in which "the language of hunger" and the sounds of grammelot are not based on any specific language, here, the audience's recognition of American English as well as the performer's 
command of stereotypic sounds are central to the parody. This is another instance in which Fo is inspired by earlier tradition, for, foreign language grammelot evolved greatly in the work of commedia dell arte troupes.

As commedia dell arte developed and the troupes toured they accessed a greater diversity of cultures. Since troupes performed similar pieces to an array of audiences, they relied increasingty on the flexibility grammelot alforded them. Fo is said to have noted grammelot developed through this touring as early as the fifteenth and sixteenth centuries: "Dario Fo attributes to the players of the 1400 s and 1500 s the invention of the onomatopoeic rambling speech. . . "4 Fo also explicitly remarks that grammelot developed outside of Italy, when the players confronted audiences with different idioms.

It pains me to have to deliver a blow to Italians patriotic sentiment, but the phenomenon of improvised comedy, with gags and grammelot. was born in this country only in embryo. It developed and grew almost entirely outside Italy. (Fo, Tricks 62-63)

By using an imaginary language that was not idiomatic, the actors counteracted what the political arena seemed bent on forming — stable borders. As the case the Comédiens Italiens, who established themselves in France in 1660, suggests, intercultural communication was possible and even popular. This troupe combined linguistic play in their work and increasingly took into account the bilingual context of the theatre in which performers worked in one language (Italian) and the audience spoke another language (French). In this complex linguistic atmosphere, Domenico Biancolelli, the hailed Comédiens Italiens performer, evolved a stage persona that combined French, Italian, and onomatopoeic sounds in orchestrated virtuosity that gained him the affectionate nickname "Domenique," thus demonstrating his acceptance by the French as one of their own.

In those years, when performing at the various French venues, Italian actors, like their French colleagues, had often to cleverly dodge the censors who imposed limitations on them, particularly on their ability to mock religious or political figures, and often, in the case of the Italiens, their ability to perform in French. 5 To avoid being closed down, they resorted to a variety of inventive techniques so as not to "enact regular plays," meaning plays including dialogues in French, which became so successful that they invited audiences to see the techniques themselves. Some of the methods of suhterfuge included: the use of monologues (thus avoiding the limitations on dialogues); splendid forms of mime in which language was spoken off stage 
while mimicked speech was performed on stage; scrolls which were incorporated within the performance and used to show text visually to the audience, allowing actors to perform without speech; and grammelot, in which the idea of language was conveyed without actual language being spoken (Duchartre 110). By buying tickets and being present at the performances, the audience even passively, became part of an act of subversion initiated by the actors.

In addition to the practical benefit of using grammelot, there were other reasons for incorporating the technique. Marisa Pizza remarks that whereas some explain the technique merely as a means of avoiding censorship, as can be seen in the case of the Comédiens Italiens, in Fo's case, grammelot enables a "refusal to speak in the language of porver." 6 And it is this dangerous aspect of grammelot that belies its subversive potential. In fact, Fo himself was susceptible to criticism and censor from a variety of bodies up to his 1997 legitimation by the Nobel committee (Pizza 21).

After a century-long hiatus, the interest in the practice of grammelot, or grmmmelotage, as it was called, arouse again. This time, the French Vieux Colombier Theatre (itself influenced by pantomime and commedia dellarte indirectly) established an experimental approach to language on the stage by introducing verbal games aimed at conveying universal expression unhindered by linguistic borders. The works of Jacques Copeau, Michel SaintDenis, and others at the Vieux Colombier school are particularly noted for challenging the audience's attitucte to theatrical language by evolving "evocative sounds" meant to suggest and convey without relying on semantics or on a common lexical pool. ${ }^{7}$ the linguistic inventiveness which ensued may have inspired Fo to continue in pursuit of what the earlier commedia clell arte players had proved to work: an invented nonsensical language to be conveyed to the delight of various audience members.

\section{The Mechanics of Grammelot}

For grammelot to work it needs to overcome two obstacles: it must present itself in a fluid and believable way so as to suggest a language, and it must be able to convey meaning. The first objective clepends entirely on the performer's command of the enactment of language: his or her ability to fuse the sounds with an inner coherence, to "sell" his sentences as sentences, the words as distinct and weighty units and the paragraphs as such. For the second objective to be achieved, the actor must co-create the language with his audience, taking into account the association they would have with the particular sounds the actor chooses. The material of his performance (the 
Words) must be meaningful and suggestive to the atudience as well as to himself so that both parties tacitly "agree" to platy the game together.

To suggest a language, along with the rhythms and cadences of expression, a stereotypical sound base which alludes to the language must be selected. These "most familiar tonal and sound stereotypes of a language," must be linked by rhythms and tones, pauses, and emphatic volume shifts which audience and player alike associate with language (Fo, Tricks 57-58). By providing a prologue of sorts, Fo suggests, the actor allows his audience to be informed of the thematic content of the grammelot. Earlier performers often gave their audiences program books which would have done the same: give the audience a general idea of what the characters were pursuing and how the plot was driven. So the game board, so to speak, is provided for the "players" - the audience and actors.

Seen in this light, grammelot is not merely a spontaneous expression. Rather, in order for it to work, a given grammelot must be constructed in a way highly aware of its audience. Regarding the actual construction of grammelot, I have noted the internal structure is composed of repeated. rhyming and rhythmic units. The grammelot must adclitionally be accompanied by extra-linguistic signals such as facial expressions, physical movement, and emotive vocalizations. Signals made to the audience, for instance an actor raising his voice to get the audience's attention are useful in preempting a grammelot section. These extra-linguistic methods all help to frame the segment of grammelot for the audience.

In "The Lesson of Scapino in French Grammelot," Fo provides a good example of the myriad gestures and expressions which the actor may incorporate in tandem with the physicalized speech to make him or herself understood (Tricks 68). In this case, Fo borrows a plot line which he attributes to Molière, a combination of Don Juan and Tartuffe. which stages the commedia dellarte - derived character Scapino as buffoonish teacher to a young gentleman (Tricks 63-64). Fo suggests that the teacher was originally intended to be a Jesuit and that the comic commedia dell arte type Scapino. or Scapin, as he was known in France, was chosen instead in order to avoid censorship by the powerful French clergy (63-64). In the course of this "lesson" on etiquette and beliavior, the servant-teacher's missive would have blatantly mocked the French clergy by exhorting the young man not to wear the frilly attire of noblemen, selecting instead a more "plain black, tight-fitting suit with buttons," clearly suggesting Jesuit fashion (65). In addition, the young man would be taught "how to put on an act of humility, how to behave like a shy, timid soul, terrilied of the things of the big, bad world - 
all the better to stay in power" (66). Throughout, these satirical directives would be enacted by Scapino (or Fo, in this latter day version) in grammelot with the aid of gestures, facial expressions and occasional vocal emissions of actual French phrases.

Initially, in the act of warming the audience to the piece, Fo narrates the story of this fictional rogue, and so, identifies sign-posts within the narrative that the auclience can recall churing the ensuing grammelot segment. He provicles the following "prologue" to the grammelot:

Scapino, master extraordinaire of the part of aging domestic, a man of great experience and wisdom, laid down the laws of good conduct in society, beginning with style of attire. It was the fashion of the time for noblemen to clon extravagant wigs, cut in styles that were, to say the least, grotesquel

Scapino's advice was to the point: "No wigs, no ribbons, no frills. You must appear modest and humble, so gather up your hair behind your neck, and there is an end of it.'(65, emphasis in Fo)

In grammelot performance of Scapino's lesson, Fo performes this narration as follows:

He [Scapino] introduces himself in the classical pose of the aristocrat, all polish and refinement, presenting himself as though he were a tailor's dummy. He starts off with a mimed description of an enormous periwig covering the head, drawing attention to the presence of rows of curls and ringlets, keeping up a commentary in semi-intelligible sounds which recall French speech. He details the operation of combing out the wig, which, as he proceeds, swellsout until it becomes as big as a large ball, whose weight and awkwardness make him lose balance. The wig snaps shut over his face like a trap-door. He pulls out hair by the handful, hauls the wig this way and that, heares a sigh, picks hairs out of his mouth and eye and exclaims peremptorily: 'pas de perruques!' He mimes the actof ripping off the wig and hurling it to the ground. (68)

In this enactment, by noting that Scapino's body is as a "tailor's dummy," Fo identilies Scapino as a scaffolding upon which the actor clrapes the words as much as the gestures of the narration. So that the "mimed clescription" of the wig: pulling the rig's curls and stationing the head piece with bobby pins is accompanied by bubloly, round sounds that themselves suggest the Waves of hair and the ringlets in the wig. ${ }^{8}$ The climaxing act of combing and being frustrated by the wig introduces a duet-like refrain of the bubbly "happy" ringlet sounds and the annoyed admonishing directives Scapino 
seems to give his wig. Finally, the angry hurling of the wig and the statement pas de pemaques! underscores the inutility of wigs while allowing a French phrase to cement to the audience, by the action of hurling and by the French sounds, and the meaning of the tirade.

As can be seen in this example. most important is equipping the audience with the tools it needs to co-create the imaginary language. In providing a performance theory of Dario Fo's work, Antonio Scuderi refers to the importance of creating a "framing" device, a concept he borrows from Gregory Bateson, which Scuderi defines as setting the given performance within a particular "interpretive frame" (Scucleri 19-47). Beyond meta-narrational devices, such as direct addresses to the audience, the "framing" of a grammelot segment enables the performer to set it apart from the more ordinary spoken sections of the performance. In order to create a reliable spectator, then, the performer must initially make clear to his audience what language is being imitated with the grammelot. Unless the audience knows the performer is using a given foreign language grammelot in a specific instance, it may not find the language funny or appropriate. Once the identification of the language has been established, the audience responds to the linguistic structural elements: the phonic units and the morphemic units, cadences, as well as the rhythms and tones of the language.

For the audience to access grammelot, the actor must broach the conveyance of grammelot on a wwo fold level. First, the performer must remore the grammelot section from the other performed material in such a way that the actor brackets it, or "frames it," setting this experience apart for the auclience. The audience must willingly accept this premise set by the performer in order to be properly engaged by the grammelot. Second, the performer must implicate his audience within his grammelot. In other words, the formulation of grammelot must be based on an understanding of the language and expectations of the audience. On a linguistic level, the performer must incorporate semantic, syntactical, morphological and phonetic features of the audience's language, together with anticipatory vocal, extra-verbal, and gestural signs particular to the performance with the grammelot.

\section{Audience/Performer Co-Creation of the Text}

Clearly, communication during a grammelot segment is enabled by a far subtler process than merely these mechanics. On a psychological level, there is a tacit complicity among the audience members and actors alike to engage in a process of externalizing what is usually the private realm of each person's imagination. If this basic acceptance is lacking, the atudience will shut 
down its ability to understand and the grammelot will remain a meaningless gurgle of sounds. To this end, Mitchell notes that in a televised enactment of Mistero buffo Fo recounts an experience in which people walked out of his enactment of "The American Technocrat," the scientific grammelot to which I referred earlier. Mitchell explains that some Americans walked out of Fo's Paris performance of this scene "precisely because they couldn't understand a word of what he was saying, but could detect he was satirizing Americans" (13). To suggest the deeper exchange which takes place between the audience and the performer during grammelot enactments, I will make use of the eminent French Phenomenologist Maurice Merleau-Ponty and his explication of the physicality implicit in speech.

In The Body as Expression, and Speech, Merleau-Ponty offers a phenomenological analysis of utterance which elucidates the relationship of the grammelot embodier to language. In this essay, Merleau-Ponty discusses the "gestural meaning, which is immanent in speech" (179). He gives the following example with regards to words and thought: "When I fix my eyes on an object in the half-light, and say: 'It is a brush', there is not in my mind the concept of a brush, under which I subsume the object, and which moreover is linked by frequent association with the word 'brush', but the word bears the meaning, and, by imposing it on the object. I am conscious of reaching that object" (177). Here, words are likened to gesture, in that words enable the thinker to reach an object which would otherwise exist only as an abstraction. Words enable a concretization of objects. But the notion of words as gestures also suggests a kinetic element in language. And this physical element of language is a helpful conceptualization for grammelot. For, though it is buffoonish, grammelot is nonetheless likened to a gesture made from one speaker to another person and from one language and cultural nexus to another one.

In The Body as Expression, and Speech, Merleau-Ponty also discusses the necessary interplay between thought and speech. "If speech presupposed thought, if talking were primarily a matter of meeting the object through a cognitive intention or through a representation, we could not understand why thought tends torvards expression as towards its completion, why the most familiar thing appears incleterninate as long as we have not recalled its name, why the thinking subject himself is in a kind of ignorance of his thoughts as long as he has not formulated them for himself or even spoken and written them, as is shown by the example of so many writers who begin a book without knowing exactly what they are going to put into it. A thought limited to existing for itself, independently of the constraints of speech and 
communication, would no sooner appear than it woukl sink into the unconscious, which means that it would not exist even for itself" (177). In MerlealuPonty's analysis, speech does not presuppose thought nor is thought completely distinct from speech. Rather, speech is necessary for thought.

Similarly, grammelot depends on its being "performed;" it cannot exist on the page but is created as it is uttered. Merleatl-Ponty"s notion of "embodiment" in language is applicable for grammelot. Nerleatu-Ponty does not speak in terms of "performativity" but in terms of "embodiment:" embodied language and the embodiment of language in speech. The notion of embodied language refers to the physicality of speech - its ability to be changed, distorted and manipulated in utterance in order to maximize its expressiveness. Differently, when one speaks with an accent, the words that conce out of the mouth seen dis-embodied from the person who is uttering them because the words are normally uttered differently. The accented speech which results often can surprise the speaker, and, in turn, reflect back onto the speaker an identity other than that he or she normally has. In other words, the experience of uttering language differently from how one normally speaks enables the speaker to think of him or herself differently and "perform" differently. Often, this means that the body language will begin to shift, and that the tone will change, making the speaker appear different.

Therefore, both language and the performance of language influence speech. In this sense, Merleau-Ponty's emphasis on the fact that neither speech precedes thought nor thought precedes speech is illuminating in terms of the "embodiment" of speech. To "perform" language in grammelot involves a complex reciprocal exchange in which the actor shapes the word and the word shapes speech. ${ }^{9}$ In grammelot, the "speech act" may perform in a dual sense: it may simulate a "speech act" as it occurs in life, but more to the point, the articulation of grammelot within the performance space allows the actors to create language.

Merleau-Ponty analyzes the experience of utterance by suggesting that "for the speaking subject, to express is to become aware of; le does not express just for others, but also to know himself what he intends" (Body' 90). Relating back to the actor who wishes to express foreign grammelot, the pretended speech allows the actor to actualize thought by the expression of nonsense language. Of course, in grammelot, the actor has an idea of what to purvey and actualizes this idea for the audience through the use of nonsense language. Therefore, the intended conveyance of meaning is pre-conceived and this is slightly different from Merleau-Ponty. But, in actualizing the grammelot, which is improvised, the performer invents amalgamated sounds and 
rhythms in a way that he has not "memorized," in a way that is alive and dynamic and depends on the moment in which he makes the utterance. ${ }^{10}$

In this sense, the actor's grammelot is a surprise, similar to Merleau-Ponty's articulation of surprise in utterance. The actor's grammelot has brought him to speaking a "language" which he cannot speak in ordinary life. The actor's relationship to his or her own body, his or her own self, has changed through this utterance in the same way a person feels (es)strange(d) when uttering words in a foreign accent. There is a fascination with the strangeness of the sounds made and then an estrangement from the self with the realization that the sounds have come from one's own body and that the sounds are different from those one ordinarily experiences as coming from the body. The grammelot has taught its embodier something about his or her own conception of language, speech and the self. The strange utterance brings about a confrontation also with other lambent potentialities. Similar to the experience of wearing a mask and fincing the body is freed to move differently from the way it ordinarily does, so, the grammelot creates a kind of "verbal mask" which results in the speaker changing his or her utterance in a surprising way. ${ }^{11}$ There is also a confrontation with the speaker's ideas about a particular language, since in pretending to speak the language, the actor will come up with a particular group of sounds, a particular tone and a rhythm. He would, in fact suggest to the audience and also to himself, his notion of the structure and sound of a particular language.

This idea, when applied to grammelot, suggests the open-ended nature of the technique which is of particular importance to improvisation. The actor's expression of meaning cannot be completed until the utterance is made. At the same time, the utterance is not completely realized unless it is said. The particular "words" which the actor would enunciate evoke associations in the audience which would create for each audience member a different meaning. For a performer to express meaning to an entire audience, the performer must choose sound and rhythm combinations which will be meaningful in some way for most of the audience. Depending on the skill of the performer, the selection of phonic units, combined with particular rhythms, would result in his audience's understanding of the grammelot.

\section{Subverting Cultural Boundaries: \\ Grammelot as an Enabler of a Common Space}

To explain the necessity of speech for thought, Merleau-Ponty suggests that a true understanding of another person is facilitated by language. In order to understand another, one must speak like another. This would mean 
an "ability to think according to others" since thought, for Mertealte-Ponty; is revealed in speech (Body' 179). The implication of all of this for theatre is not necessarily that forms such as commedia dell arte attempt to genuinely comprehend other cultures by adopting their language within performance. Undoubtedly, commedia dell arte manipulated foreign languages within performance for comic ends. However, with regards to the means used to achieve these ends, Merleau-Ponty's emphasis on speech as a tool in empalthy suggests the commedia dell ante performer's need to utilize speech, alloeit fictional speech, in order to access a character who is foreign to him. The fact that the fictional speech is nonsense means the actor's depiction is consciously approximating a foreign persona. The speaker and the audience recognize the impersonation of a foreigner through language as playful within this context.

Merleau-Ponty's indication of the importance of language in thinking "according to otbers" necessitates an explanation of how one may take up another's speech. He answers this by suggesting that implicit within language is its "existential manner," a kind of blueprint of the structure of the language (179). Therefore, speaking the language of another would reveal the other's thoughts, leading to greater understanding of this person. "I begin to understand a philosophy by feeling my way into its existential manner, by reproducing the tone and accent of the philosopher. In fact, every language conveys its own teaching and carries its meaning into the listener's mind" (179). In relation to this, Merleau-Ponty mentions the experience of being in a foreign country and attempting a foreign language. He suggests that, just as in the example of philosophy, one may understand the language when one engages with it. " [I]n a foreign country, I begin to understand the meaning of words through their place in a context of action, and by taking part in a communal life . . " (179). This means that Merleau-Ponty's notion helps to explain how the commedia dell'arte performer, by enunciating a "foreign" language, would begin to speak it. The actor's grammelot would rely on techniques similar to a person's attempt to understand a foreign language. In this regard, it is useful once again to return to Fo's notion of grammelot as dependent on the attribution of stereotypical sounds to a language $\mathrm{X}$ by culture $\mathrm{Y}$. In any given grammelot, the stereotypical sounds can be constructed based on integrating syntactical, phonetical, morphological and perhaps generally rhythmic and tonal perceptions of a given language.

For the actor, grammelot is a unique performance experience since in speaking grammelot, the performer relates to language differently than he normally would in life and on stage. In utilizing improvisation within gram- 
melot performance, the actor is keeping his utterances fresh, since their content or sequence remains open-ended. ${ }^{12}$ Furthermore, in speaking in a selfinvented language, the actor performs language as a non-stable communication system. At the same time, the performer relies on grammelot to convey meaning. And so, the actor adheres to a notion of language as transnational. As such, the actor's performance is not guided by national boundaries so much as it is grounded in universal communication. The performer, then, exists within language and beyond language at the same time, inventing a lingual cosmology in order to transcend national languages. The actor is thus embedded in a "rorldmaking" process for which the grammelot is more of a transformation than a performance. ${ }^{13}$ The utterances deflect the mother tongue of both the actor and the audience member in favor of a mutually shared language "space" where actor and audience member converge. This provocative threshold defines the actor in a different way from that in which he is identified when he performs a monolingual written text.

Grammelot enables the performer to increase his spectrum of expression by partially freeing him from the confines of language. (Although often the grammelot enactor will rely on a group of sounds or words which are referential and resonate a meaning in the audience.) The actor can choose to incorporate any group of sounds or any version of a language within his scene, mixing it to form utterances. However, these utterances do not comprise an artificial language, like the computer language DOS or Esperanto, both of which invent new words which have a referential and denotational value. Rather, the utterances rely on the associative and physical element of language to convey meaning.

Fo illustrates how grammelot can be constructed. Implicit in any construction of grammelot is also an awareness that grammelot exists within an actor/auctience interplay. In grammelot, the actor mirrors the audience's relation to foreign language. The performer enacts the mixed frustration and desire people feel when confronted with a code they cannot readily decipher. The grammelot actor does the impossible by speaking a language that is imaginary. For the audience this is cathartic in a dual sense. First, grammelot reflects people's complex relation with language which is at once something people must master and yet, something they are continually frustrated by. When the aludience witnesses the actor's efforts at enunciating the words of the imagined language, they witness a reflection of their own attempts at language(s). Second, since grammelot is based on imaginary utterances and non-sequiturs, its ability to communicate is almost contradictory to its nature. Therefore, the audience member feels a constant tension 
between knouting it is not possible to understand the language of grammelot and at the same time understanding the language. The paradox caluses a cognitive confusion which brings up the normally hidden frustration inlerent to language - its transparency at times and our acute awareness of it as a mechanism separated from ourselves at other times. In the theatre context, this distillation of the problematic of language, bringing up questions of identity and our alienation from ourselves, is potentially therapeutic. On the one hand, the audience becomes aware of the otherwise camouflaged difficulty of language and at the same time, the audience releases that tension brought on by the difficulty of language through laughter.

\section{Conclusion}

In conclusion, grammelot never attempts to actualize a particular language but enacts a communicative space in which either a fictional version of a particular language or an entirely imaginative language is presented. It is an act of intervention which clisrupts the actor and audience's given pattern of communication and forces the audience itself into an active role as a language shaper. For the actor, grammelot provides a unique performance phenomenon since it shifts the actor's relation to language, making language a far more flexible medium. But the performer exists within a dynamic system in the theatre and the receiver (the audience), who witnesses grammelot, not only enables grammelot to take place but also informs its construction. In so doing, the apparently "untheatrical" language of nonsense becomes a heightened performance in which audience and actor boundaries are obscured as both are mutually-dependent in the creation of the text of the performance.

\section{Hebreu' Lniversity, Jerusalem}

\section{NOTES}

1 For a cliscussion of the importance of the giullari for Fo, as well as the origin of the term, see Mitchell 21-22. For the different nomenclature of these itinerant traveling performers, see Scuderi 8 .

2 See the reprints of these engravings in Duchartre.

3 The Staning Zanni grammelot (il grammelot dello Zammi affamato) is presented as part of Mistero Buffo, which Tony Mitchell points oul relies heavily on grammelot as well as on a language "which Fo describes as 'fifteenth century Padano," a mixture of the var- 
ious dialects of the Po valley, Lombardian, Venetian and Piedmontese which are adapted, sometimes modernized, and frequently parts are completely invented, and even treated as an incomprehensible foreign language which relies on the actor's physical illustration and verbal explanation" (12). An example from Fo's Mistero buffo can best illustrate the difference between Padano and grammelot. In the segment of The Resurrection of Lazamis (Resurrezione di Lazzaro) the first character appears and says in Padano:

Oh scusé! Oh l'è questo ol simitéri, campusanto duè che vai a fa ol süscitamento d'ul Lazzaro? (102-103)

(Excuse me! is this the cemetery, where they will do the resurrection of Lazarus?)

4 "Darjo Fo attribuisce ai comici del Quattrocento e del Cinquecento, l'invenzione dello sproloquio onomatopeico. .." Pizza 105.

${ }^{5} \mathrm{~A}$ central example of censorship is the incident which forced the taliens out of Paris between $169^{-}$and 1716 . The reason for the exile was a performance that was perceived as an insult to the King's mistress, Mme. de Maintenon, although, as scholars such as Kenneth and Laura Richards have pointed out, the insult may merely have been the official reason for banishing a troupe that had alreacly become problematic for the monarchy due to their flagrantly satirical work (262). The limitations on the use of French within performance were imposed in order to protect the monopoly the Comédie Française had with regards to performing plays in French, as noted by Duchartre (109).

6 "Credo che la vera ragione del recitare in grammelot è il rifiuto dell'accettazione della lingua del potere" (Pizza 105).

7 Saint-Denis writes about the "grummelotage" that his Compagnie des Quinze developed (39).

8 I am referring to the recorded performance of Dario Fo and Franca Rame, $1 /$ meglio di mistero buffo.

9 The reference here is to Austin's articulation of the fact that saying, as in marriage vows, is often doing.

10 This changes when grammelot is scripted. However, often the scripted version records a performed grammelot, and, in that sense, even the written version is often influenced by improvisation.

11 While the speaker is "freed" to express him or herself differently, tension increases, the farther from the "self" the speaker ventures. As the utterances become less and less similar to normative speech, the feeling of estrangement and distance grows. Therefore, while the utterances are being made there is a simultaneous awareness of the distance the utterance creates from his or her normal pattern of speech.

12 However, improvisation does not necessarily suggest the actor extemporize in a merely inspired way: instead, improvisation is often based on skillful preparation and rehearsing, even if there is no completely written script. The complex interplay between preparation and extemporization increases in cases of more than one performer impro- 
vising in a given scene. Pietropaolo emphasizes the collaborative aspect of commedici dellante improvisation. He writes ". . in the commedia dellante improwisation is principally a question of collaboration among the cast for the purpose of conjoining signs draw from the repertoires of the individual actors and harmonized in to a plot-creating strateg!" (168). Pietropaolo elahorates that the collal boration among actors is achieved through a "stochastic composition process" which means that each actor selects his regnent of performance from an acknowledged inventory shared by his fellow actors.

13 For more on the notion of "world making," see Goodman 101.

\section{WORKS CITED}

Austin, J. L. How' to Do Things with Words. Cambridge: Harvard LP, 1962.

Duchartre. Pierre Louis. The Italian Comed1: Trans. Randolph T. Weaver. New York: Dover Pub, 1966.

Farce de Lâ̂tre Pierre Pathelin. Trans. Jean-Claude Aubailly: Paris: Société décition d'enseignement supérieur. 19-9.

Fo, Dario. Mistero buffo: Giullarata popolare. Ed. Franca Rame. Verona: Bertani, 1974.

The Tricks of the Trade Trans. Joe Farell. Ed. Stuart Hood. London: Methuen Drama. 1991.

Goodman, Nelson. Ways of Worldmaking. Indianapolis: Hatchett Pub. Co, 1978. Il meglio di mistero buffo. By Dario Fo. Perf. Dario Fo, Franca Rame. Videocassette. C.T.F.R., 1991.

Merleau-Ponty, Maurice. "The Body as Expression, and Speech." Phenomenology' of Perception. Trans. Colin Smith. London: Routledge and Kegan Paul. 1962. . "On the Phenomenology of Language." Trans. Richard C. McCleary.

Evanston: Northwestern LP. 1961.

Mitchell. Tony. Dario Fo: People's Court Jester. London: Methuen, 1984.

Pietropaolo, Domenico. "Improvisation as a Stochastic Composition Process." The Science of Buffoonery. Ed. Domenico Pietropaolo. Ottawa: Dowehouse Editions inc., 1989.

Pizza, Marisa. Il gesto. la parola. lazione: poetica, drammaturgia e storia dei monologhi di Dario Fo. Roma: Bulzoni, 1996.

Richards, henneth and Laura. The Commedia dell Ante: A Documentary Histon:

Oxford: Basil Blackwell Lid, 1990.

Saint-Denis, Michel. Training for the Theatre: Premises and Promises. Ed. Suria Saint-

Denis. New York: Theatre Arts Books, 1982.

Scuderi, Antonio. Dario Fo and Popular Performance. Ottawa: Legas, 19o8. 